\title{
FAKTOR-FAKTOR YANG BERHUBUNGAN DENGAN KEJADIAN ABORTUS
}

\author{
Rika Rahmi, Rachmawati, PS. Kurniawati \\ Politeknik Kesehatan Kementerian Kesehatan Bengkulu, Jurusan Kebidanan, \\ Jalan Indragiri Nomor 3 Padang Harapan Bengkulu \\ e-mail: rika.rahmi@ymail.com
}

\begin{abstract}
The purpose of this study was to determine the factors related to the abortion.
Design Cross Sectional study using primary data, the population of pregnant women $\leq 20$ weeks bleed by 2011 as many as 309 respondents, the study sample was taken with accidental sampling amounted to 55 people with primigravida as exclusion criteria, using the format of data collection, analyzed by univariate, bivariate with Chi-Square test and multivariate multiple logistic regression. The results show $(40 \%)$ of maternal aged $<20$ or $>35$ years $(32.7 \%)$ had parity $>3$, $(30.9 \%)$ no history of abortion, (40\%) pregnancies distance $<2$ years $(18,2 \%)$ no maternal disease, $(76.3 \%)$ experienced abortion. The results of Chi-Square test, age obtained $p=0.006, p=0.038$ obtained parity, history of abortion obtained $\mathrm{p}=0.012$, spacing pregnancies obtained $\mathrm{p}=0.030$, maternal disease obtained $\mathrm{p}=0.565$ showed there is significant relationship between age, parity, history of abortion, the distance pregnancy by abortion, and there is no significant relationship between maternal disease and abortion. Distance pregnancy dominant factors associated with the incidence of abortion (OR: 12.364).
\end{abstract}

Key Words : Abortion, Pregnancy Spacing, Parity, Maternal Disease, History Of Abortion, Age

\begin{abstract}
Abstrak : Tujuan penelitian ini adalah untuk mengetahui faktor-faktor yang berhubungan dengan kejadian abortus.

Desain penelitian menggunakan pasang silang dengan data primer, populasi ibu hamil $\leq 20$ minggu yang mengalami perdarahan tahun 2011 sebanyak 309 responden, sampel penelitian ini diambil dengan accidental sampling berjumlah 55 orang dengan primigravida sebagai kriteria eksklusi, menggunakan format pengumpulan data, dianalisis secara univariat, bivariat dengan uji ChiSquare dan multivariat dengan regresi logistik berganda.

Hasil penelitian menunjukkan $(40 \%)$ ibu hamil usia $<20$ atau $>35$ tahun, $(32,7 \%)$ memiliki paritas $>3,(30,9 \%)$ ada riwayat abortus, $(40 \%)$ jarak kehamilan $<2$ tahun, $(18,2 \%)$ ada penyakit pada ibu, $(76,3 \%)$ mengalami abortus. Hasil uji Chi-Square usia diperoleh $\mathrm{p}=0,006$, paritas diperoleh $\mathrm{p}=$ 0,038 , riwayat abortus diperoleh $\mathrm{p}=0,012$, jarak kehamilan diperoleh $\mathrm{p}=0,030$, penyakit ibu diperoleh $\mathrm{p}=0,565$ menunjukkan ada hubungan bermakna antara usia, paritas, riwayat abortus, jarak kehamilan dengan kejadian abortus, serta tidak ada hubungan yang bermakna antara penyaktit ibu dengan kejadian abortus. Jarak kehamilan faktor dominan yang berhubungan dengan kejadian abortus (OR: 12,364).
\end{abstract}

Kata Kunci : Abortus, Jarak Kehamilan, Paritas, Penyakit Ibu, Riwayat Abortus, Usia

Angka kematian maternal dan neonatal merupakan indikator pelayanan kesehatan dan derajat kesehatan suatu bangsa. Berdasarkan Survei Demografi dan Kesehatan Indonesia (SDKI) tahun 2003, Angka Kematian Ibu (AKI) di Indonesia masih berada pada 307/100.000 kelahiran hidup. Angka ini tercatat masih tinggi dibandingkan negara tetangga Malaysia sebesar 36/100.000 kelahiran hidup, bahkan di Vietnam 160/100.000 kelahiran hidup.
Pada tahun 2007 AKI mengalami penurunan, yaitu 228/100.000 kelahiran hidup, namun angka ini masih jauh dari target Milleneum Development Goals (MDGs) pada tahun 2015 yaitu 102/100.000 kelahiran hidup, (Depkes RI, 2008).

Setiap tahunnya diperkirakan ada 5 juta kelahiran di Indonesia, sekitar 100.000 dari kelahiran tersebut berakhir dengan kematian. Penyebab langsung kematian ibu terkait kehamilan dan persalinan terutama 
adalah perdarahan (28\%), eklamsi (24\%), infeksi (11\%), partus lama (5\%), abortus (5\%), emboli (3\%), komplikasi masa puerperium (8\%), lain-lain (11\%). Komplikasi abortus berupa perdarahan dan infeksi, serta komplikasi akibat abortus yang tidak aman yang terselubung dalam angka perdarahan menyebabkan abortus merupakan salah satu penyumbang tingginya Angka Kematian Ibu (Depkes RI, 2007).

Angka Kematian Ibu (AKI) di Provinsi Bangkulu tahun 2010 yaitu 115,2/100.000 kelahiran hidup, sedangkan AKI di Provinsi Bengkulu tahun 2011 sebesar 120/100.000 kelahiran hidup, dengan kematian ibu bersalin 20 orang, kematian ibu hamil 9 orang dan kematian ibu nifas 11 orang. (Dinas Kesehatan Provinsi Bengkulu, 2011).

Abortus adalah pengeluaran hasil konsepsi sebelum janin dapat hidup diluar kandungan dan pengakhiran kehamilan sebelum janin mencapai berat 500 gram atau kehamilan < 20 minggu. Komplikasi abortus yang secara potensial fatal adalah sepsis yang disebabkan oleh abortus yang tidak lengkap, yang sebagian atau seluruh produk pembuahan masih tersisa di dalam dan sisa abortus yang tidak lengkap tidak jarang dapat mengakibatkan perdarahan yang banyak dapat menimbulkan syok, dan tidak jarang kematian (Wiknjosastro, 2007).

Faktor-faktor yang menyebabkan abortus sebagian tidak diketahui secara pasti, akan tetapi ada beberapa faktor penyebab terjadinya abortus, yaitu faktor pembuahan hasil konsepsi, kelainan pada plasenta, penyakit ibu, dan kelainan traktus genitalis. Faktor lain yang dapat mempengaruhi kejadian abortus adalah umur, paritas, riwayat abortus, jarak kehamilan, penyakit infeksi akut, kebiasaaan hidup, dan status gizi (Manuaba, 2008).

Data dari catatan rekam medik di Ruang C1 Kebidanan RSUD dr. M. Yunus Bengkulu pada tahun 2010 menyebutkan bahwa terdapat $186(52,8 \%)$ kasus abortus dari 352 kasus perdarahan pada ibu hamil dan pada tahun 2011 terdapat $268(86,7 \%)$ kasus abortus dari 309 orang ibu hamil yang mengalami perdarahan. Survey awal peneliti pada tanggal 8-13 Oktober 2012 di Poli Kebidanan dan Ruang Mawar RSUD dr. M. Yunus Bengkulu terdapat 7 orang yang mengalami kejadian abortus diantaranya 1 orang ibu dengan paritas grandemultipara, 3 ibu dengan primipara, $3 \mathrm{ibu}$ dengan multipara, 3 ibu dengan riwayat abortus sebelumnya, serta 4 ibu dengan jarak kehamilan $<2$ tahun.

Berdasarkan data-data dan uraian tersebut, maka penulis tertarik untuk melakukan penelitian mengenai "faktorfaktor yang berhubungan dengan kejadian abortus."

\section{BAHAN DAN CARA KERJA}

Penelitian ini menggunakan rancangan survei analitik, dengan pendekatan pasang silang dimana variabel independen dan dependen pada obyek penelitian diukur atau dikumpulkan secara simultan atau dalam waktu yang bersamaan. Populasi dalam penelitian ini adalah semua ibu hamil <20 minggu yang mengalami perdarahan dan tercatat pada register di RSUD dr. M. Yunus Bengkulu tahun 2011, yaitu berjumlah 309 orang. Sampel dalam penelitian ini berjumlah 55 orang yang diambil dengan cara accidental sampling yaitu dengan mengambil kasus atau responden yang kebetulan ada atau tersedia.

Pengumpulan data dilakukan dengan menggunakan data primer. Pengolahan data dilakukan dengan analisis univariat. Metode statistik yang digunakan oleh peneliti dengan tujuan untuk menggambarkan distribusi frekuensi masingmasing variabel. Analisis bivariat untuk mengetahui hubungan variabel independen dan dependen, serta analisis multivariat untuk mengetahui faktor risiko yang paling dominan terhadap variabel dependen menggunakan analisis regresi logistik sederhana. 
HASIL

\section{Analisis Univariat}

Analisis univariat dilakukan untuk mengetahui distribusi frekuensi distribusi frekuensi usia, paritas, riwayat abortus, jarak kehamilan, penyakit ibu dan kejadian abortus.

Tabel 1. Distribusi Frekuensi Usia, Paritas, Riwayat Abortus, Jarak Kehamilan, Penyakit Ibu dan Kejadian Abortus di Ruang Kebidanan C1 Mawar RSUD Dr. M. Yunus Bengkulu Tahun 2012

\begin{tabular}{|c|c|c|}
\hline Variabel & $\begin{array}{c}\text { F } \\
(n=55)\end{array}$ & $\%$ \\
\hline \multicolumn{3}{|l|}{$\begin{array}{l}\text { Kejadian Perdarahan kehamilan } \\
\text { pada usia kehamilan } \leq 20 \\
\text { minggu }\end{array}$} \\
\hline - $\quad$ Abortus & 7 & 67,3 \\
\hline - $\quad$ Tidak Abortus & 18 & 32,7 \\
\hline \multicolumn{3}{|l|}{ Usia } \\
\hline - $\quad<20$ tahun atau $>35$ tahun & 22 & 40 \\
\hline 20-35 tahun & 33 & 60 \\
\hline \multicolumn{3}{|l|}{ Paritas } \\
\hline$-\quad>3$ & 18 & 32,7 \\
\hline $1-3$ & 37 & 67,3 \\
\hline \multicolumn{3}{|l|}{ Riwayat abortus } \\
\hline - $\quad$ Ada riwayat abortus & 17 & 30,9 \\
\hline - $\quad$ Tidak ada riwayat abortus & 38 & 69,1 \\
\hline \multicolumn{3}{|l|}{ Jarak Kehamilan } \\
\hline$-\quad<2$ tahun & 22 & 40 \\
\hline - $\quad \geq 2$ tahun & 33 & 60 \\
\hline \multicolumn{3}{|l|}{ Penyakit ibu } \\
\hline - $\quad$ Ada penyakit ibu & 10 & 18,2 \\
\hline - $\quad$ Tidak ada penyakit ibu & 45 & 81,8 \\
\hline
\end{tabular}

Hasil penelitian disajikan dalam tabel 1, yaitu diketahui bahwa dari 55 sampel ibu yang mengalami perdarahan pada usia kehamilan $\leq 20$ minggu, sebagian besar $(67,3 \%)$ mengalami abortus, se-bagian (40\%) kejadian pada ibu berusia $<20$ atau $>35$ tahun, hampir sebagian $(32,7 \%)$ pada paritas $>3$, serta hampir sebagian $(30,9 \%)$ pada ibu yang memiliki riwayat abortus, dan hampir sebagian $(40 \%)$ pada jarak kehamilannya $<2$ tahun, lalu sebagian kecil $(18,2 \%)$ pada ibu yang memiliki penyakit menyertai kehamilan.

\section{Analisis Bivariat}

Analisis bivariat pada penelitian ini dilakukan untuk mengetahui hubungan antara usia, riwayat abortus, jarak ke- hamilan, penyakit ibu dengan kejadian abortus di Ruang Kebidanan C1 Mawar RSUD dr. M. Yunus Bengkulu Tahun 2012.

Tabel 2 menunjukkan 22 ibu hamil, yang berusia $<20$ atau $>35$ tahun hampir seluruh $(90,9 \%)$ mengalami abortus. Hasil Chi-square menunjukkan nilai $p$ 0,006 < 0,05 menunjukkan bahwa ada hubungan yang bermakna antara usia dengan kejadian abortus, dengan nilai OR 7,601 yang berarti bahwa ibu hamil yag berusia $<20$ atau $>35$ cenderung berisiko 7,601 kali mengalami abortus dibanding ibu hamil yang berusia 20-35.

Dapat dilihat juga dari 18 ibu hamil, yang memiliki paritas $>3$ hampir seluruh $(88,9 \%)$ mengalami abortus. Hasil Chisquare menunjukkan nilai p $0,038<0,05$ menunjukkan bahwa ada hubungan yang bermakna antara paritas dengan kejadian abortus, dengan nilai OR 4,313 yang berarti bahwa ibu hamil dengan paritas $>3$ cenderung beresiko 4,313 kali mengalami abortus dibanding ibu hamil dengan paritas 1-3.

Dari 17 ibu hamil, yang memiliki riwayat abortus hampir seluruh $(94,1 \%)$ mengalami abortus. Hasil Chi-square nilai p $0,012<0,05$ menunjukkan bahwa ada hubungan yang bermakna antara riwayat abortus dengan kejadian abortus, dengan nilai OR 6,386 yang berarti bahwa ibu hamil dengan riwayat abortus cenderung berisiko 6, 386 kali mengalami abortus dibanding ibu hamil yang tidak memiliki riwayat abortus.

Tabel 2 juga menunjukkan bahwa dari 22 ibu hamil, yang jarak kehamilannya $<2$ tahun, hampir seluruh $(86,4 \%)$ mengalami abortus dengan nilai p $0,030<0,05$ menunjukkan bahwa ada hubungan yang bermakna antara jarak kehamilan dengan kejadian abortus, dengan nilai OR 4,711 yang berarti bahwa ibu hamil dengan jarak kehamilan <2 tahun 4,711 kali mengalami abortus dibanding ibu hamil dengan jarak kehamilan $\geq 2$ tahun.

Dari 10 ibu hamil, yang memiliki penyakit yang menyertai kehamilan, 
hampir seluruh (80\%) mengalami abortus. Hasil Chi-square menunjukkan nilai $\mathrm{p}$ $0,565>0,05$ menunjukkan bahwa tidak ada hubungan yang bermakna antara penyakit ibu dengan kejadian abortus.

Tabel 2. Hubungan Usia, Paritas, Riwayat Abortus, Jarak Kehamilan, Penyakit Ibu dengan Kejadian Abortus di Ruang Kebidanan C1 Mawar RSUD. Dr. M. Yunus Bengkulu Tahun 2012.

\begin{tabular}{|c|c|c|c|c|c|c|c|c|}
\hline \multirow{3}{*}{ Variabel } & \multicolumn{4}{|c|}{ Abortus } & \multirow{2}{*}{\multicolumn{2}{|c|}{ Total }} & \multirow{3}{*}{ Nilai p } & \multirow{3}{*}{ OR } \\
\hline & \multicolumn{2}{|c|}{ Ya } & \multicolumn{2}{|c|}{ Tidak } & & & & \\
\hline & $\mathrm{F}$ & $\%$ & $\mathrm{~F}$ & $\%$ & $\mathrm{~F}$ & $100 \%$ & & \\
\hline Usia & & & & & & & & \\
\hline - $<20$ tahun atau $>35$ tahun & 20 & 90,9 & 2 & 9,1 & 22 & 100 & 0,006 & 7,601 \\
\hline - 20-35 tahun & 17 & 51,5 & 16 & 48,5 & 33 & 100 & & \\
\hline Paritas & & & & & & & & \\
\hline$->3$ & 16 & 88,9 & 2 & 11,1 & 18 & 100 & 0,038 & 4,313 \\
\hline$-1-3$ & 21 & 56,8 & 16 & 43,2 & 37 & 100 & & \\
\hline Riwayat abortus & & & & & & & & \\
\hline - Ada riwayat abortus & 16 & 94,1 & 1 & 5,9 & 17 & 100 & 0,012 & 6,386 \\
\hline - Tidak ada riwayat abortus & 21 & 55,3 & 17 & 44,7 & 38 & 100 & & \\
\hline Jarak Kehamilan & & & & & & & & \\
\hline$-<2$ tahun & 19 & 86,4 & 3 & 13,6 & 22 & 100 & 0,030 & 4,711 \\
\hline$-\geq 2$ tahun & 18 & 54,5 & 15 & 45,5 & 33 & 100 & & \\
\hline Penyakit ibu & & & & & & & & \\
\hline - Ada penyakit ibu & 8 & 80 & 2 & 20 & 10 & 100 & 0,565 & 0,331 \\
\hline - Tidak ada penyakit ibu & 29 & 64,4 & 16 & 35,6 & 45 & 100 & & \\
\hline
\end{tabular}

Analisis Multivariat

Tabel 3. Tahapan Regresi Logistik Faktor Usia, Paritas, Riwayat Abortus, Jarak Kehamilan dan Penyakit pada Ibu dengan Kejadian Abortus di Ruang Kebidanan C1 Mawar RSUD dr. M. Yunus Bengkulu Tahun 2012

\begin{tabular}{ccc}
\hline Variabel & Exp (B) & Sig. \\
\hline Usia & 9,412 & 0,006 \\
Paritas & 6,095 & 0,028 \\
Riwayat Abortus & 12,952 & 0,018 \\
Jarak Kehamilan & 5,278 & 0,020 \\
Penyakit Ibu & 2,207 & 0,352 \\
\hline
\end{tabular}

Berdasarkan tabel 3, dapat dilihat bahwa ada 1 variabel yang memiliki nilai $p$ value > dari 0,25 yaitu penyakit ibu $(0,352)$ sehingga variabel penyakit ibu tersebut tidak dapat diikutsertakan dalam model multivariat.

Berdasarkan tabel 4, Setelah variabel paritas dikeluarkan, dihitung perbandingan OR sebelum dan sesudah paritas dikeluarkan, ada perubahan OR yang >10\% dengan demikian variabel paritas dimasukkan kembali kedalam permodelan. Ke- mudian dilihat dari tabel, masih ada variabel yang memiliki $\mathrm{p}$ value $>0,05$ yaitu variabel riwayat abortus, sehinga permodelan berikutnya riwayat abortus dikeluarkan dari permodelan.

Setelah variabel riwayat abortus dikeluarkan, dihitung perbandingan OR sebelum dan sesudah riwayat abortus dikeluarkan, ada perubahan OR yang > $10 \%$ dengan demikian variabel riwayat abortus dimasukkan kembali kedalam permodelan. Dari tabel tidak ada lagi $\mathrm{p}$ value yang > 0,05 sehingga hasil akhir permodelan adalah variabel jarak kehamilan merupakan variabel yang paling berpengaruh pada penelitian ini, dibuktikan dengan nilai eksponen beta yang paling besar dimiliki jarak kehamilan yaitu mencapai 12,364 dengan nilai $\mathrm{p}<0,05$. Artinya ibu yang jarak kehamilannya $<2$ tahun berpeluang 12,364 kali terjadi abortus dibanding ibu yang jarak kehamilannya $\geq 2$ tahun 
Tabel 4. Hasil Analisis Regresi Logistik Berganda Faktor yang Berhubungan dengan Kejadian Abortus di Ruang Kebidanan C1 Mawar RSUD. Dr. M. Yunus Bengkulu Tahun 2012.

\begin{tabular}{lcccccccc}
\hline \multirow{2}{*}{ Faktor independen } & \multicolumn{2}{c}{ Tahap 1 } & \multicolumn{2}{c}{ Tahap 2 } & \multicolumn{2}{c}{ Tahap 3 } & \multicolumn{2}{c}{ Tahap 4 } \\
\cline { 2 - 9 } & OR & Sig. & OR & Sig. & OR & Sig. & OR & Sig. \\
\hline Usia & 12,408 & 0,051 & 23,911 & 0,001 & 14,234 & 0,034 & 12,408 & 0,051 \\
Paritas & 2,261 & 0,479 & - & - & 2,121 & 0,569 & 2,261 & 0,479 \\
Riwayat ab & 11,066 & 0,049 & 10,503 & 0,053 & - & - & 11,066 & 0,049 \\
Jarak kehamilan & 12,364 & 0,006 & 11,437 & 0,007 & 15,519 & 0,001 & 12,364 & 0,006 \\
\hline
\end{tabular}

\section{PEMBAHASAN}

\section{Hubungan Usia dengan Kejadian Abortus}

Berdasarkan hasil penelitian didapatkan bahwa sebagian besar responden $(60 \%)$ memiliki usia antara 20 sampai 35 tahun. Kehamilan yang baik terjadi pada saat ibu yang berusia antara 20-35 tahun pada usia tersebut sangat produktif untuk terjadinya kehamilan dengan jarak kehamilan lebih dari 2 tahun (depkes RI, 2001). Dalam penelitian ini kejadian abortus banyak terjadi pada usia 20-35 tahun, hal ini dapat dilihat dari faktor lain yang memengaruhi kejadian abortus seperti paritas, riwayat abortus, jarak kehamilan $<2$ tahun, serta penyakit yang menyertai kehamilan ibu.

Hasil penelitian ini menunjukkan bahwa terdapat hubungan yang bermakna antara usia dengan kejadian abortus dengan nilai $p=0,006$. Hal ini sesuai dengan pendapat Manuaba (2008) yang menyebutkan usia ibu memiliki kontribusi terhadap terjadinya abortus. Usia ibu dianggap penting karena ikut menentukan proknosis kehamilan karena dapat mengakibatkan kesakitan baik ibu maupun janin. Kejadian abortus disebabkan karena kurangnya pemahaman tentang waktu yang aman untuk melakukan hubungan seksual yang mengakibatkan terjadinya kehamilan diusia $<20$ tahun sedangakan kehamilan diusia tua >35 tahun disebabkan oleh faktor minimnya pemahaman tentang bahaya kehamilan diusia tua.

Dari hasil analisis penelitian didapatkan bahwa hampir seluruh $(90,9 \%)$ ibu yang berusia $<20$ atau $>35$ tahun mengalami abortus. Sejalan dengan pendapat Winkjosastro (2007) wanita yang hamil pada usia yang terlalu muda yaitu $<20$ tahun, secara fisik alat-alat reproduksinya belum siap untuk menerima hasil konsepsi dan secara psikologi belum cukup dewasa dan matang untuk menjadi seorang ibu, sedang wanita hamil pada usia lanjut yaitu $>35$ tahun, proses faal tubuhnya sudah mengalami kemunduran berupa elastisitas otot-otot panggul dan sekitar organ-organ reproduksi lain, keseimbangan hormonalnya mulai terganggu sehingga terjadi berbagai resiko kehamilan, diantaranya abortus, solusio plasenta dan plasenta previa. Menurut Cunningham (2005) peningkatan resiko abortus dari $12 \%$ pada wanita yang berusia kurang 20 tahun dan meningkat menjadi $26 \%$ pada wanita yang berusia lebih dari 35 tahun. Usia kurang dari 20 tahun adalah umur yang dianggap terlalu muda untuk hamil karena endometrium belum siap menerima hasil konsepsi. Pada usia kurang dari 20 tahun sistem transfer plasenta kejanin tidak seefisien wanita dewasa karena organ reproduksi belum matur. Sedangkan usia lebih lebih dari 35 tahun organ reproduksi dan fungsi organ tubuh lainnya sudah mulai menurun, walaupun mereka berpengalaman tetapi kondisi badan dan kesehatannya sudah menurun sehingga dapat mempengaruhi janin intrauterine (Jame, 2002).

Hasil penelitian ini sejalan dengan yang dilakukan oleh Firman (2010) yang menyatakan bahwa ada hubungan antara usia ibu dengan kejadian abortus, dengan nilai $\mathrm{p}$ value 0,024 dan nilai OR 2,167 , namun penelitian ini tidak sejalan dengan yang dilakukan oleh Yudi. A (2005) yang menyatakan bahwa tidak terdapat hubungan antara usia dengan kejadian abortus, dengan diperolehnya nilai $\mathrm{p}>0,05$. 
Hasil penelitian ini juga didapat bahwa dari 22 responden yang berusia $<20$ tahun atau >35 tahun, sebagian kecil responden $(9,1 \%)$ tidak mengalami abortus. Begitu juga pada ibu hamil yang berusia 20-35 tahun ditemukan sebagian responden $(51,5 \%)$ mengalami abortus. Hal ini terjadi karena bukan hanya faktor usia yang dapat menyebabkan abortus, banyak faktor yang dapat menyebabkan abortus, diantaranya faktor hasil konsepsi, kelainan pada plasenta, penyakit ibu, kelainan pada rahim dan faktor predisposisi seperti anemia, status gizi, jarak kehamilan dan riwayat abortus (Wiknjosastro, 2007).

Harapan untuk mencegah dan mengurangi angka kejadian abortus dapat dilakukan dengan beberapa langkah diantaranya dengan memberikan penyuluhan tentang rencana kehamilan pada usia reproduksi sehat yakni antara usia 20 sampai 35 tahun, memberikan pendidikan pada ibu hamil tentang deteksi dini resiko kehamilan serat cara mengenal tanda-tanda bahaya dalam kehamilan. Menganjurkan ibu untuk memeriksakan kehamilannya sejak diketahui terlambat menstruasi atau dirasakan tanda-tanda kehamilan (Nanik, 2009).

\section{Hubungan Paritas dengan Kejadian Abortus}

Berdasarkan hasil penelitian didapatkan bahwa hampir sebagian responden $(32,7 \%)$ dengan paritas grandemultipara. Menurut Sriwahyanti (2012) mengatakan paritas merupakan salah satu faktor risiko kehamilan, paritas grandemultipara mempunyai risiko komplikasi obstetri lebih tinggi dibanding paritas primipara dan multipara. Pada kehamilan ibu yang telah memiliki jumlah anak 4 orang atau lebih, keadaan rahim ibu teregang oleh adanya janin, bila terlalu sering melahirkan, rahim akan semakin lemah. Bila ibu telah melahirkan 4 orang anak atau lebih, maka perlu diwaspadai adanya gangguan pada waktu kehamilan, persalinan, dan nifas.
Hasil penelitian ini menunjukkan terdapat hubungan yang bermakna antara paritas dengan kejadian abortus dengan nilai $p=0,038$. Hasil penelitian sesuai dengan pendapat Manuaba (2008) yang menyatakan bahwa risiko kematian janin ditentukan dengan jumlah paritas seorang ibu. Grandemultipara berisiko mengalami abortus lebih tinggi karena keadaan organ reproduksi sudah mulai melemah terutama lingkungan endometrium di daerah korpus uteri sudah mengalami kemunduran fungsi dan berkurangnya vaskularisasi. Hal ini terjadi karena degenerasi dan nekrosis pada bekas luka implantasi plasenta pada kehamilan sebelumnya di dinding endometrium. Adanya kemunduran fungsi dan berkurangnya vaskularisasi di daerah endometrium menyebabkan daerah tersebut tidak subur lagi dan tidak siap menerima hasil konsepsi, sehingga pemberian nutrisi dan oksigenisasi kepada hasil konsepsi kurang maksimal, hal ini dapat mengganggu sirkulasi darah ibu ke janin. Keadaan ini akan mengganggu pertumbuhan dan perkembangan hasil konsepsi, dimana hasil konsepsi tidak dapat berimplantasi secara maksimal, yang mengakibatkan kematian dan lepasnya sebagian atau seluruh hasil konsepsi dari tempat implantasinya. Bagian yang terlepas ini dianggap benda asing oleh uterus sehingga uterus berusaha untuk mengeluarkannya dengan cara berkontraksi

Berdasarkan hasil penelitian didapatkan bahwa hampir seluruh responden $(88,9 \%)$ yang memiliki paritas $>3$ mengalami abortus. Hasil penelitian ini didukung oleh pendapat Wiknjasatro (2007), yang menyatakan bahwa abortus spontan akan semakin meningkat dengan bertambahnya paritas. Paritas tinggi (lebih dari 3) mempunyai angka kematian maternal dan kematian janin dalam rahim lebih tinggi. Penelitian ini juga sesuai dengan pendapat Cunninghams (2005) yang menyatakan bahwa resiko abortus spontan semakin meningkat dengan bertambahnya paritas disamping dengan semakin lanjutnya usia 
ibu serta ayah, lebih tinggi paritas, lebih tinggi risiko terjadi abortus spontan.

Hasil penelitian ini sesuai dengan pendapat Wiknjosastro (2008) yang mengatakan bahwa paritas yang aman ditinjau dari sudut kematian maternal adalah paritas 2-3. Jumlah paritas yang tinggi memberikan gambaran tingkat kehamilan yang banyak, dapat menyebabkan berbagai resiko kehamilan termasuk abortus. Semakin banyak kelahiran yang dialami seorang ibu, semakin tinggi resikonya untuk mengalami komplikasi. Kehamilan yang berulang-ulang dapat menyebabkan perubahan atau kerusakan pembuluh darah pada uterus yang mempengaruhi sirkulasi nutrisi ke janin, sehingga dapat mempengaruhi pertumbuhan dan perkembangan janin dalam kandungan atau dapat menyebabkan komplikasi yang dapat memicu terjadinya abortus. Hasil penelitian ini juga didukung oleh pendapat Cunninghams (2005) yang mengatakan bahwa resiko abortus semakin meningkat dengan bertambahnya paritas disamping dengan semakin lanjutnya usia ibu, lebih tinggi paritas, lebih tinggi resiko terjadinya abortus. Penelitian ini juga sejalan dengan hasil penelitian Widyastuti (2007) yang menyebutkan bahwa $59,5 \%$ abortus terjadi pada paritas risiko tinggi (lebih dari 3 ).

Hasil penelitian ini juga menunjukkan bahwa bahwa dari 18 responden yang memiliki paritas $>3$, sebagian kecil responden $(11,1 \%)$ tidak mengalami abortus. Begitu juga pada ibu hamil yang memiliki paritas 1-3 ditemukan sebagian responden $(56,8 \%)$ mengalami abortus. Hal ini terjadi karena bukan hanya faktor paritas yang dapat menyebabkan abortus, banyak faktor yang dapat menyebabkan abortus, diantaranya faktor hasil konsepsi, kelainan pada plasenta, penyakit ibu, kelainan pada rahim dan faktor predisposisi seperti anemia, status gizi, jarak kehamilan dan riwayat abortus (wiknjosastro, 2007). Seperti hal nya dengan yang dilakukan oleh Yudi. A (2005) yang menyatakan bahwa tidak terdapat hubungan antara paritas dengan kejadian abortus, dengan diperolehnya nilai $\mathrm{p}$ Value sebesar 1,000 yang lebih besar dari nilai alpha 0,05 .

Upaya yang dapat dilakukan oleh petugas kesehatan seperti bidan dapat meningkatkan promosi kesehatan tentang paritas yang sehat untuk hamil, kepatuhan untuk memeriksakan kehamilannya menjaga pola makan, dan memberikan informasi kesehatan yang cukup terutama pada ibu-ibu hamil yang beresiko diharap-kan akan dapat merubah perilaku yang kurang baik kepola perilaku hidup sehat (nanik, 2009)

\section{Hubungan Riwayat Abortus dengan Kejadian Abortus}

Berdasarkan hasil penelitian didapatkan bahwa hampir sebagian responden $(30,9 \%)$ memiliki riwayat abortus. Menurut Nanik (2009) salah satu penyebab terjadinya abortus adalah karena adanya riwayat obstetri yang buruk pada kehamilan sebelumnya. Dimana apabila seorang ibu pernah mengalami abortus pada kehamilan sebelumnya, hal ini merupakan ancaman untuk mengalami abortus pada kehamilan kedua disebabkan karena abnormalitas perumbuhan janin yang kemungkinan bersifat euploeidik dengan abnormalitas maternal.

Hasil penelitian ini juga menunjukkan bahwa terdapat hubungan yang bermakna antara riwayat abortus ibu dengan kejadian abortus dengan nilai $p=0,012$. Berdasarkan hasil penelitian didapatkan bahwa hampir seluruh responden $(94,1 \%)$ yang memiliki riwayat abortus mengalami abortus. Hal ini sesuai dengan pendapat Cunninghams (2005), yang mengatakan bahwa kejadian abortus diduga mempunyai efek terhadap kehamilan berikutnya, baik pada timbulnya penyulit kehamilan maupun pada hasil kehamilan itu sendiri. Wanita dengan riwayat abortus mempunyai risiko yang lebih tinggi untuk terjadinya abortus berulang.

Penelitian ini sejalan dengan penelitian yang dilakukan oleh Nanik (2009) yang mengatakan bahwa ada hubungan 
antara riwayat abortus dengan kejadian abortus, dimana ibu yang ada riwayat abortus pada kehamilan sebelumnya mempunyai peluang untuk mengalami abortus sebesar 16 kali tinggi dibandingkan dengan ibu yang tidak ada riwayat abortus sebelumnya. Sehingga riwayat abortus pada kehamilan sebelumnya juga merupakan faktor yang dapat menyebabkan terjadinya abortus.

Ibu hamil yang memiliki riwayat abortus dapat mengalami abortus yang berulang pada kehamilan seterusnya yang dapat diikuti berbagai komplikasi seperti peritonitis yang dapat menambah besarnya kemungkinan abortus, timbulnya jaringan parut uterus yang dapat mengakibatkan ruptur uteri pada kehamilan berikutnya, perlekatan intra uteri sebagai akibat dari tindakan kuretase pada abortus yang terinfeksi, yang dapat mengakibatkan terjadinya abortus yang berulang, trauma fisik dan trauma emosional terhadap peristiwa yang pernah dialami ibu yang menurut fenomena medis dikaitkan dengan abortus habituali (Nanik, 2009)

Hasil penelitian ini juga menunjukkan bahwa dari 17 responden yang memiliki riwayat abortus sebagian kecil responden $(5,9 \%)$ tidak mengalami abortus. Begitu juga pada ibu yang tidak memiliki riwayat abortus ditemukan sebagian besar responden $(55,3 \%)$ mengalami abortus. Hal ini terjadi karena bukan hanya faktor riwayat abortus yang dapat menyebabkan terjadinya abortus, banyak faktor yang dapat menyebabkan abortus, diantaranya faktor hasil konsepsi, kelainan pada plasenta, penyakit ibu, kelainan pada rahim dan faktor predisposisi seperti anemia, status gizi, dan jarak kehamilan (Wiknjosastro, 2007).

Kurangnya informasi dari petugas kesehatan kepada ibu hamil bahwa riwayat abortus akan memeberikan dampak/resiko terhadap kehamilannya saat ini kemungkinan menjadi penyebab, sehingga ibu hamil kurang meningkatkan deteksi dini terhadap kehamilannya saat ini dimana hal ini dapat meningkatkan resiko abortus. Upaya pencegahan yang dapat dilakukan adalah dengan memberikan penyuluhan pada ibu hamil diharapkan jangan bekerja terlalu lelah sehingga bisa membahayakan janin yang dikandungnya (Nanik, 2009)

\section{Hubungan Jarak Kehamilan dengan Kejadian Abortus}

Berdasarkan hasil penelitian didapatkan bahwa hampir seluruh responden $(86,4 \%)$ yang memiliki jarak kehamilan <2 tahun mengalami abortus. Hasil penelitian ini juga menunjukkan bahwa terdapat hubungan yang bermakna antara jarak kehamilan dengan kejadian abortus dengan nilai $p=0,030$. Hasil penelitian ini didukung pendapat Manuaba (2008) yang menyatakan bahwa kesuburan endometrium bisa dipengaruhi oleh gizi ibu yang kurang karena anemia atau terlalu pendek jarak kehamilan. Penelitian ini juga sesuai dengan teori menurut Cunninghams (2005) yang mengatakan bahwa gizi ibu kurang karena anemia atau terlalu pendek jarak kehamilan akan menjadi salah satu faktor predisposisi meningkatnya kemungkinan abortus.

Penelitian ini dipertegas dengan pendapat Supriyadi (2006) yang menyatakan bahwa pada kehamilan jarak dekat, kemungkinan kekurangan gizi amat besar terutama pada ibu yang menyusui, nutrisi ibu jadi berkurang sehingga janin semakin kekurangan gizi. Selain itu juga bisa mengakibatkan keguguran karena selama menyusui ada pengaruh oksitosin pada isapan mulut bayi. Oksitosin ini membuat perut ibu menjadi tegang atau kontraksi. Pada kehamilan muda, bisa terjadi perdarahan atau ancaman keguguran. Kehamilan dengan jarak diatas 24 bulan sangat baik bagi ibu karena kondisi ibu sudah normal kembali, dimana endometrium yang semula mengalami trombosis dan nekrosis karena pelepasan plasenta dari dinding endometrium telah mengalami pertumbuhan dan kemajuan fungsi seperti keadaan semula dikarenakan dinding-dinding endometrium mulai re- 
generasi dan sel-sel epitel endomerium mulai berkembang. Bila saat ini terjadi kehamilan, endometrium telah siap menerima dan memberikan nutrisi pada hasil konsepsi.

Hasil penelitian ini juga sejalan dengan pendapat Gazali (2009) yang menyatakan bahwa Jarak yang dianjurkan untuk melahirkan berikutnya adalah berkisar 2-3 tahunya karena alat reproduksi sudah siap dan kondisi ibu juga sudah pulih. Penelitian The Demographis and Health Survey menyebutkan bahwa anak-anak yang dilahirkan 3-5 tahun setelah kakaknya, memiliki kemungkinan hidup sehat 2,5 kali lebih tinggi daripada yang berjarak kehamilan kurang dari 2 tahun. Hasil penelitian ini juga sejalan dengan penelitian yang dilakukan oleh Putri. R (2011), yang menyatakan bahwa terdapat hubungan antara jarak kehamilan dengan kejadian abortus, dengan diperolehnya nilai $\mathrm{p}$ Value sebesar 0,016 yang lebih kecil dari nilai alpha 0,05 .

Hasil penelitian ini juga menunjukkan bahwa dari 22 responden yang jarak kehamilannya $<2$ tahun sebagian kecil responden $(13,6 \%)$ tidak mengalami abortus. Begitu juga pada ibu yang jarak kehamilannya $\geq 2$ tahun ditemukan sebagian besar responden $(54,5 \%)$ mengalami abortus. Hal ini terjadi karena bukan hanya faktor jarak kehamilan yang dapat menyebabkan terjadinya abortus, banyak faktor yang dapat menyebabkan abortus, diantaranya faktor hasil konsepsi, kelainan pada plasenta, penyakit ibu, kelainan pada rahim dan faktor predisposisi seperti anemia, status gizi, dan riwayat abortus (Wiknjosastro, 2007).

Petugas kesehatan seperti bidan atau dokter hendaknya lebih meningkatkan lagi program yang dilakukan untuk menurunkan angka kejadian abortus dengan melakukan penyuluhan atau konseling dan menganjurkan agar ibu hamil dengan jarak kehamilan minimal 2 tahun, selain itu bidan atau dokter dapat memberikan penyuluhan tentang jumlah kelahiran yang baik bagi kesehatan reproduksi seorang wanita (nanik, 2009)

\section{Hubungan Penyakit Ibu dengan Kejadian Abortus}

Berdasarkan hasil penelitian didapatkan bahwa hampir seluruh responden $(81,8 \%)$ tidak memiliki penyakti yang menyertai kehamilan, dan sebagian kecil responden $(18,2 \%)$ memiliki penyakit yang menyertai kehamilan. Berdasarkan hasil penelitian juga didapatkan bahwa hampir seluruh responden $(80 \%)$ yang memiliki penyakit yang menyertai kehamilan mengalami abortus. Hasil penelitian ini juga menunjukkan tidak terdapat hubungan yang bermakna antara penyakit ibu dengan kejadian abortus dengan nilai $\mathrm{p}=0,565$.

Hal ini tidak sejalan dengan pendapat Wiknjosastro (2007) yang mengatakan bahwa penyakit ibu dapat secara langsung mempengaruhi pertumbuhan janin dalam kandungan melalui plasenta, beberapa penyakit yang dimaksud adalah penyakit infeksi yang menyebabkan demam tinggi (tifoid, malaria dan DBD) karena kematian fetus dapat disebabkan karena toksin dari ibu. Ibu yang mempunyai penyakit paru berat, malnutrisi, avitaminosis, gangguan metabolisme, hipertiroid serta anemia ya-ng dapat mempengaruhi pertumbuhan janin melalui gangguan nutrisi dan peredaran $\mathrm{O} 2$ menuju sirkulasi retroplasenter. Selanjutnya yaitu penyakit menahun ibu seperti hipertensi, dan penyakit diabetes melitus.

Hasil penelitian juga menunjukkan dari 45 ibu hamil yang tidak memiliki penyakit, sebagian besar $(64,4 \%)$ mengalami abortus. Hal ini dapat saja terjadi karena banyak faktor yang dapat menyebabkan abortus, diantaranya faktor resiko meliputi faktor hasil konsepsi, kelainan pada plasenta, kelainan pada rahim dan faktor predisposisi seperti usia, jarak kehamilan, anemia, status gizi, dan riwayat abortus (Wiknjosastro, 2007). 


\section{Faktor yang Paling Besar Hubungannya terhadap Kejadian Abortus}

Dari hasil analisis multivariat, diperoleh bahwa jarak kehamilan memiliki nilai eksponen beta yang paling tinggi diantara variabel independen yang lain yaitu mencapai 12,364. Hal ini memberikan arti bahwa jarak merupakan variabel yang dapat pengaruh paling besar terhadap kejadian abortus.

Menurut Krisnadi (2005) jarak yang terlalu dekat (kurang dari dua tahun) berhubungan dengan meningkatnya risiko kejadian keguguran, bayi dengan berat badan lahir rendah (kurang dari 2.500 gram), kematian janin dan kematian bayi. BKKBN (2007) juga menyatakan bahwa faktor resiko pertama yang disebabkan oleh jarak kehamilan yang terlalu dekat adalah terjadinya abortus.

Suatu proses kehamilan akan terjadi bila 4 aspek penting terpenuhi yaitu adanya ovum dan spermatozoa, serta terjadinya konsepsi dan nidasi (Depkes RI, 2004). Sementara untuk terjadinya nidasi diperlukan lingkungan endometrium yang baik, subur dan telah siap untuk tempat nidasi atau implantasi hasil konsepsi, apabila kondisi endometrium tidak memungkinkan / belum siap menerima implantasi hasil konsepsi, maka akan menghambat proses pertumbuhan dan perkembangan hasil konsepsi, sehingga bisa terjadi kecacatan, kematian janin bahkan kemungkinan terbesar adalah terjadi abortus. Kesuburan endometrium bisa dipengaruhi oleh gizi ibu yang kurang karena anemia atau terlalu pendek jarak kehamilan (Manuaba, 2008).

Supriyadi (2006) juga menyatakan bahwa pada kehamilan jarak dekat, kemungkinan kekurangan gizi amat besar terutama pada ibu yang menyusui, nutrisi ibu jadi berkurang sehingga janin semakin kekurangan gizi. Selain itu juga bisa mengakibatkan keguguran karena selama menyusui ada pengaruh oksitosin pada isapan mulut bayi. Oksitosin ini membuat perut ibu menjadi tegang atau kontraksi. Pada kehamilan muda, bisa terjadi perdarahan atau ancaman keguguran. Kehamilan dengan jarak diatas 24 bulan sangat baik bagi ibu karena kondisi ibu sudah normal kembali, dimana endometrium yang semula mengalami trombosis dan nekrosis karena pelepasan plasenta dari dinding endometrium telah mengalami pertumbuhan dan kemajuan fungsi seperti keadaan semula dikarenakan dinding-dinding endometrium mulai regenerasi dan sel-sel epitel endomerium mulai berkembang. Bila saat ini terjadi kehamilan, endometrium telah siap menerima dan memberikan nutrisi pada hasil konsepsi.

Jarak yang dianjurkan untuk melahirkan berikutnya adalah berkisar 2-3 tahunya dimana alat reproduksi sudah siap dan kondisi ibu juga sudah pulih. Penelitian The Demographis and Health Survey menyebutkan bahwa anak-anak yang dilahirkan 3-5 tahun setelah kakaknya, memiliki kemungkinan hidup sehat 2,5 kali lebih tinggi daripada yang berjarak kehamilan kurang dari 2 tahun (Gazali, 2009).

\section{KESIMPULAN}

Ibu hamil yang dirawat dengan perdarahan di Ruang Kebidanan C1 Mawar RSUD. Dr. M. Yunus Bengkulu, sebagian besar mengalami abortus. Ibu hamil yang dirawat dengan perdarahan di Ruang Kebidanan C1 Mawar RSUD. Dr. M. Yunus Bengkulu, hampir sebagian memiliki usia <20 tahun atau >35 tahun. Ibu hamil yang dirawat dengan perdarahan di Ruang Kebidanan C1 Mawar RSUD. Dr. M. Yunus Bengkulu, hampir sebagian memiliki paritas >3. Ibu hamil yang dirawat dengan perdarahan di Ruang Kebidanan C1 Mawar RSUD. Dr. M. Yunus Bengkulu, hampir sebagian memiliki riwayat abortus. Ibu hamil yang dirawat dengan perdarahan di Ruang Kebidanan C1 Mawar RSUD. Dr. M. Yunus Bengkulu, hampir sebagian memiliki jarak kehamilannya $<2$ tahun mengalami abortus. Ibu hamil yang 
dirawat dengan perdarahan di Ruang Kebidanan C1 Mawar RSUD. Dr. M. Yunus Bengkulu, sebagian kecil memiliki penyakit yang menyertai kehamilan. Ada hubungan yang bermakna antara usia dengan kejadian abortus di RSUD Dr. M. Yunus Kota Bengkulu dengan nilai $\mathrm{p}=$ 0,006 . Ada hubungan yang bermakna antara paritas dengan kejadian abortus di RSUD Dr. M. Yunus Kota Bengkulu dengan nilai $\mathrm{p}=0,038$. Ada hubungan yang bermakna antara riwayat abortus dengan kejadian abortus di RSUD Dr. M.

\section{DAFTAR RUJUKAN}

Arikunto, S. 2006. Prosedur Penelitian Suatu Pendekatan Praktek. Rineka Cipta. Jakarta

Asmawati, dkk. 2011. Jurnal kesehatan, Faktorfaktor yang berhubungan dengan Kejadian Abortus pada Ibu hamil di puskesmas seputih raman kabupaten lampung tengah 2 (1) : 258-264

BKKBN. 2004. Kehamilan, Persalinan Pasca Melahirkan. $\quad$ http://www.bkkbn.com. Diakses 25 Septembr 2012

-2007. Hindari Kehamilan 4 Terlalu. http://www.bkkbn.com. Diakses 31 januari 2013

Budiarto, E. 2002. Biostatistik Untuk Kedokteran Dan Kesehatan Masyarakat. EGC. Jakarta

Cunningham dkk, 2005. Obstetri Williams Edisi 21, EGC. Jakarta

Dinas Kesehatan Provinsi Bengkulu, 2011. Profil Kesehatan Bengkulu 2011. Bengkulu

Ensiklopedia. 2009.2 Jarak. http://www.ensiklopedia.com. Diakses 2 Septembr 2012

Emanuel, E. 2008. Jarak Antar Kehamilan dan Risiko Abortus Spontan di Kabupaten Purworejo Jawa Tengah. Tesis. Universitas Gajah Mada. Yogyakarta

Gazali, F. 2009. Atur Jarak Kehamilan. http://www.blogspot-Anreas-09.com. Diakses 27 Septembr 2012

Hidayat A. 2007. Metode Penelitian Kebidanan dan Teknik Analisis. Salemba Medika. Jakarta

Krisnadi, S.R. 2005. Hamil Saat Bayi Tiga Bulan. Jakarta. http://www.pikiran-rakyat.com. Diakses 30 Septembr 2012
Yunus Kota Bengkulu dengan nilai $\mathrm{p}=$ 0,012 . Ada hubungan yang bermakna antara jarak kehamilan dengan kejadian abortus di RSUD Dr. M. Yunus Kota Bengkulu dengan nilai $\mathrm{p}=0,030$. Tidak ada hubungan yang bermakna antara penyakit ibu dengan kejadian abortus di RSUD Dr. M. Yunus Kota Bengkulu dengan nilai $\mathrm{p}=0,565$. Jarak kehamilan adalah faktor yang paling dominan terhadap terjadinya abortus dengan nilai $\mathrm{OR}=12,364$

Kuntari. T, Agus. S, Emilia. O. 2010. Jurnal Kesehatan Masyarakat Nasional, Determinan abortus di Indonesi. 4 (5) : 223229

Manuaba, I.B.G. 2008. Ilmu Kebidanan Penyakit Kandungan dan Keluarga Berencana untuk Pendidikan Bidan. EGC. Jakarta

Mansjoer, A. 2000. Kapita Selekta Kedokteran Jilid ke 2. Media Aesculapius FKUI. Jakarta

Notoatmodjo, S. 2005. Metodelogi Penelitian Kesehatan. Rineka Cipta. Jakarta

Praputranto, A.S. 2005. Jarak Kehamilan Yang Aman.

Sastrawinata, S. 2004. Obstetri Patologi Ilmu Kesehatan Reproduksi ed.2. EGC. Jakarta

Saifuddin, A. 2002. Buku Acuan Nasional Pelayanan Kesehatan Maternal Dan Neonatal. YBPSP. Jakarta

Sriwahyanti. 2012. 4 Terlalu Dalam kehamilan. http://www.google.com. Diakses 31 januari 2013

Utomo. 2001. Fakta Mengenai Aborsi. http://www.google.com. Diakses 28 Septembr 2012

Varney, H. 2002. Buku Saku Bidan. Cetakan I : EGC. Jakarta

Wiknjosastro, H. 2007. Ilmu Kebidanan. Yayasan Bina Pustaka Sarwono Prawirohardjo, Cetakan ke-9. Jakarta

Widyastuti. 2008. Faktor-Faktor yang Berhubungan dengan Kejadian Abortus di RSUP Dr. Muhammad Hosein Palembang. http://www.google.com. Diakses 3 September 2012 